\title{
The Influence of the Learning Environment on Learner Autonomy: A comparative Study of Polish and Yemeni EFL Undergraduate Learners
}

\author{
Ammar Al-Khawlani \\ University of Warsaw, Warsaw, Poland
}

\begin{abstract}
The goal of autonomous language learning is to create an atmosphere where learners take charge of their own learning. Creating this atmosphere encounters various challenges which are partially context-specific. Influenced by the learning environment, learners of different educational contexts vary in their degree of autonomy. The present study examines the impact of the learning environment on learner autonomy at higher education. The study focuses on the differences between Polish and Yemeni EFL (English as a Foreign Language) learners with respect to their autonomy in language learning. A questionnaire was distributed to a total of 140 (59 Polish and 81 Yemeni) undergraduate learners. The questionnaire was coded into seven categories: beliefs and attitudes, planning, management, self-regulation, sources and materials, in-class responsibility, and out-of-class responsibility. Data were analysed quantitatively via SPSS (Statistical Product and Service Solutions). Independent Sample $t$-Test is used to investigate the differences between Polish and Yemeni learners and Pearson Correlation is used to perform correlational analysis among the seven categories. The results show significant differences between Polish and Yemeni learners in some of the categories as well as a significant correlation among other categories.
\end{abstract}

Keywords: learner autonomy, learning environment, self-regulation, self-learning, self-directed learning, Poland, Yemen

\section{Introduction}

To cope with the highly modern, progressive, and global learning environments, we need to consistently develop and improve skills and abilities of the learners as well as learning styles. Currently, we are experiencing a global need for learners, be it regular or non-regular students, to be "better educated, more skilled, lifelong autonomous learners who can adapt to the rapidly changing and evolving demands of the modern world" (Weinstein, Acee, Jung, \& Dearman, 2011, p. 41). This enables people to actively engage themselves in personal and social development and highly influences the progress in their environments.

Since the 1970s, researchers and practitioners have investigated the concept of learner autonomy in education generally and in foreign language learning specifically (e.g., Holec, 1981; Little, 1991; Benson, 2011). The concept of autonomy is multidimensional, which results in various perspectives and investigations administered by various scholars (e.g., Komorowska, 2014; Benson, 2011; 2008). La Ganza (2008) enumerated

\footnotetext{
Ammar Al-Khawlani, M.A., Ph.D. candidate, Department of Applied Linguistics, Institute of English Studies, University of Warsaw, Warsaw, Poland.
} 
different scholars approaching the concept from different perspectives: Benson (1997) and Pemberton, LI, Or, \& Pierson (1996) highlighted the political dimension of learner autonomy focusing on the notion of learners' "taking control" of their learning; Holec (1981) and Kohonen (1992) emphasized on the more liberal progressive notion of learners' "taking responsibility" for their learning; Wenden (1987) and Dickinson (1992) paid attention to the behavioural notion of learners' developing systematic "strategies" to help their independence in their learning; and on the humanistic notion of learners" "self-direction" and "self-initiation" of their learning (Rogers, 1961; Kenny, 1993; Savage \& Storer, 1992) as part of a process of "experimentation and discovery" (La Ganza, 2008, p. 65).

Fostering learner autonomy has been investigated in various studies (e.g., Thanasoulas, 2000; Duqin, 2002; Ismail, Singh, \& Abu, 2013; Ceylan, 2015). However, developing learner autonomy and self-direction schemes means "working with particular learning cultures" considering, in other words, the ways in which the "participants in counselling discourse negotiate the parameters of their learning encounter" which involves negotiation between "the learning authority of the counsellor and the learning aspirations of the student" (Clemente, 2003, p. 202). The importance of learner autonomy in what Smith, Kuchah, and Lamb (2018) have named as "under-resourced contexts" appears to be less salient, however, it should not be "underestimated" and is considered as "as a distinct type of context which has so far been under-researched" (Smith et al., 2018, p. 23). Therefore, the educational context plays a vital role in developing learner autonomy in which the present paper is a comparative study in two different educational contexts, Poland and Yemen.

\section{Learning Environment: Towards Autonomous Learning}

Learning environment is defined as an "extremely complex concept with a number of meanings" (Nyman \& Kaikkonen, 2013, p. 168). To facilitate the complexity of the concept and its various meanings, Nyman and Kaikkonen (2013) grouped various interpretations of the concept based on various scholars as: stressing metaphors (Mononen-Aaltonen, 1998); essential environmental features, such as contextual, open versus closed, and technological (Veermans \& Tapóla, 2006); and on different conditions of learning, such as physical, mental, local, social, technological, and didactic environment (Huttunen, 2002; Manninen et al., 2007). According to the National Core Curriculum (2004), a learning environment means "entity of psychic factors, social relations, and physical environment concerning learning and teaching" (cited in Nyman \& Kaikkonen, 2013, p. 169).

Cohn and Fraser (2013) reported two models of the learning environments: the first model by Lewin (1936), where the "interactions between the surrounding environment and an individual's personality determine each individual's behaviours in a given situation" (Cohn \& Fraser, 2013, p. 187); and the second one by Murray (1938), which was built upon Lewin's theory when he "proposed a needs-press model in which the needs of both the individual and the press of a given situation or environment both can affect the outcome of behaviour" (Cohn \& Fraser, 2013, p. 187).

In language education, the perspective of the learning environment emphasizes introducing pupils' needs and interests instead of instructional aims (Common European framework of reference for languages: Learning, teaching, assessment, 2001; National core curriculum for the upper secondary level, 2003, p. 18; Norton, 2000, p. 137) and the meaningless of learning both to the teacher and to the learner (Huttunen, 2002). The learning environments are categorized into form-oriented and meaning-oriented emancipatory learning environments in accordance with the amount of attention paid to the conditions of learning and the ways they are met (Huttunen, 2002; cited in Nyman \& Kaikkonen, 2013) 
The context of the learning process has been viewed as an important variable. Benson (2004) posited that "contextual variables of SLA research are seen as both determinants and outcomes of the learning process" (p. 19). In a similar vein, Ellis (2008) and Gass (2004) argued that there are both quantitative and qualitative differences between the second/foreign learning contexts, which may mean radical differences in both what is learned and how it is learned. Little (2017) also stressed the importance of the context in fostering learner autonomy. Developing learner autonomy may have special relevance, for instance, in less qualified educational systems, where a "dissonance often exists between what formal education offers and what many learners want or need" (Smith et al, 2018, p. 7). Larsen-Freeman (2002) explained that

$[\mathrm{L}]$ anguage users must constantly be scanning the environment, observing their interlocutors and interpreting what they are hearing/seeing, in order to make decisions about how to respond in accurate, meaningful and appropriate ways, and then carry out their decisions "online", i.e., they must then somehow activate what they have decided upon. This clearly entails a dynamic process. (Larsen-Freeman, 2002, p. 26)

She "stresses the fact that grammar should be viewed as a skill rather than a body of knowledge and refers to the ability to use linguistic features accurately, meaningfully, and appropriately" (Pawlak, 2017, p. 6).

Holec (2009) mentioned two sets of guiding pedagogical principles which can account for the numerous learning environments that are referred to by their proponents as implementations of the "autonomy" approach. In "state one type of implementation", he listed three guiding principles: "instructed learning" guided by teacher in classroom interactions or based on pre-constructed materials; "co-directed learning" which allows students to participate in the guidance of their learning; and "increasing learner responsibility" in management of the teaching programme allowing them to take part in the shaping of the programme. In the "state two type of implementations", Holec (2009) argued that this type can be reached after "state one" or as its onset which "represents a fundamental shift in perspective based on a set of different principles" including: non-instructed learning that is not guided by the teacher, nor subjected to any constraints imposed by the learning materials; focus is given to the "development of the learners' ability to self-direct their learning programme"; and aim is to produce autonomous learners by "providing learning conditions integrating language learning and learning-to-learn environments" (Holec, 2009, pp. 26-27). Holec further argued that "some implementations can be described as being border-line cases, pertaining to both state one and state two sets of principles". These are implementations associating partly co-directed and partly self-directed language learning with integrated learning-to-learn activities (Holec, 2009, p. 32). To classify autonomy in relation to the learning environments, Benson (2007) introduced a new categorization of autonomy: in classroom and beyond the classroom. This comprises self-access, Computer-Assisted Language Learning (CALL), distance learning, tandem learning, out of class learning, and self-instruction. Classroom environment may "pose a considerable threat to teenage learners as the influence of social goals on academic achievements is substantial" (Wentzel, 1999; cited in Klimas, 2017, p. 24).

\section{Autonomy: The Concept in Language Learning}

"Autonomy" is derived from Greek autos meaning self and nomos-law. Komorowska (2014) stated that the meaning of autonomy was originally "political and related to the regaining of control over a particular territory or jurisdiction by a particular administrative unit or geographical region" (Komorowska, 2014, p. 51). Benson (2011) stated that: 
[T]o its advocates, autonomy is a precondition for effective learning; when learners succeed in developing autonomy, they not only become better language learners but they also develop into more responsible and critical members of the communities in which they live. (Benson, 2011, p. 1)

Benson (2008) argued that the idea of "autonomy in learning" is essentially a construal of the relevance of broader ideas of "autonomy in life" where he focuses on the liberal concept of "personal autonomy" which originally comes from "moral and political philosophy". He went on to argue that the concept of autonomy, based on liberal philosophers, "defines the senses in which a liberal society should value and protect individual freedom" (Benson, 2008, p. 17). This does not "imply freedom of action in any given occasion, but rather a more general idea that the individual should "freely direct the course of his or her own life" (Young, 1986; quoted in Benson, 2008, p. 17).

In language learning, autonomy, described as a semantically complex term (Little \& Dam, 1998), is "widely cited" after Holec's (1981) definition, which remains the most influential for researchers (Benson 2007, p. 22). The Council of Europe's Modern Language Project led to the publication of Holec's (1981) seminal report in which he defined autonomy as "the ability to take charge of one's own learning" (cited in Benson 2007, p. 22). This definition has been the focus of renewed interest in the last decades, both in the area of educational research in general and in applied linguistics in particular.

According to Holec (1981, p. 4), the "fully-fledged" autonomous learner is able to make decisions with regard to five domains: learning goals, learning content and progression (the syllabus), learning methods and techniques, monitoring of learning progress, evaluation of learning achievement (cited in Lennon, 2012, p. 20). Autonomous learners should be seen "as persons who possess both the capacity and the freedom to steer their own learning in the direction of personal autonomy" (Benson, 2008, p. 22). White (2008) used the term "independence" as a synonym for autonomy. Independence in language learning involves:

Developing the attitudes, beliefs, knowledge, and strategies needed by learners to take actions dealing with their own learning. Independent learning in this sense is based on students' understanding of their own needs and interests and is fostered by creating the opportunities and experiences which encourage student choice and self-reliance and which promote the development of learning strategies and metacognitive knowledge. (White, 2008, p. 5)

Although Benson (2011) drew our attention to the place of goals in autonomous learning, Klimas (2017) stated that students may control their learning at three interdependent levels: control over learning management, control over cognitive processes, and control over learning content. The control over the learning management "should be understood in terms of strategies that students employ in order to plan, organize, and evaluate their learning" (Klimas, 2017, p. 23). The control over cognitive processes is "concerned with the psychology of learning, that is, particular mental processes associated with the idea of control" which play a crucial role at "attention", "reflection", "metacognitive knowledge" (Klimas, 2017, p. 23). The control over learning content "implies a capacity as well as the right to set and evaluate one's own learning goals" and she continues stating that whatever a student aims to achieve, it requires specific goals and if they are "are self-determined, the learning process becomes an authentic and dynamic experience, because it is the learner's own" (Klimas, 2017, p. 23).

As Little (1999; 2004; 2006) repeatedly argued, the development of autonomy should be guided by three universal principles: learner involvement or empowerment, learner reflection, and the target language use. Learner involvement is achieved by "encouraging students to become personally and collectively responsible as 
well as by creating appropriate conditions for students so that they are more involved" (Klimas, 2017, p. 25). Learner reflections refer to the process in which learners are stimulated to "apply critical thinking to planning, monitoring, and evaluating their learning". The appropriate target language use refers to "the necessity of using the target language as the preferred medium of classroom communication" (Klimas, 2017, p. 23). Little (2004), however, stressed the fact that all three principles are clearly interdependent.

Smith (2003) distinguished between "weak" and "strong" versions of autonomy. The "weak" version tends to view "autonomy as a capacity which students currently lack" and/or identify it with a mode of learning "which students need to be prepared for" (Smith, 2003, p. 130). The "strong" version, on the other hand, is based on the assumption that "students are, to greater or lesser degrees, already autonomous, and already capable of exercising this capacity" (Smith, 2003, p. 131). Little (2017) classified learner autonomy into three versions. The first, central to the Council of Europe's project on adult education in the 1970s, embeds "self-learning" in the interactive, dialogic processes of group work. The second version, elaborated by Henri Holec, is exclusively cognitive-organizational and individual in its orientation which treats the development of learner autonomy and the growth of proficiency in the target language as separate processes. Developed by Leni Dam, the third version of learner autonomy is concerned with classroom language learning as a set of practical procedures; it shares with the first version the view that learning is a social-interactive as well as an individual-cognitive process; and because from the beginning the target language is the principal medium of classroom communication, it sees the development of learner autonomy and the growth of target language proficiency as inextricably linked (Little, 2017, pp. 145-147). The exercise of responsible autonomy entails "self-management, which means that the educational process must be based on self-learning, a process that is guided and supported by a teacher working in an institutional framework". Self-learning "generally refers to the practice of working in groups and to the choice by participants of objectives, curriculum content, and working methods and pace" (Little, 2017, p. 147).

The success of autonomous learning environments has been attributed "to systematic use of the target language for metacognitive as well as communicative purposes" (Little, 2017, p. 155). Learner autonomy has been thoroughly investigated in various educational contexts. Table 1 represents a recent sample of selected studies in different contexts. An analysis of Table 1 highlights several salient themes.

(1) Teachers perceive learner autonomy as relevant to the notions of taking control and responsibility recurs;

(2) Teachers view learner autonomy as a desirable educational goal and a capacity that enhances the process of language learning;

(3) The percentage of teachers who feel their learners have a fair degree of autonomy is generally not high;

(4) Practically speaking, teachers appear to be less optimistic about the feasibility of implementing learner autonomy than they are about its desirability;

(5) There are number of factors that prevent the development of learner autonomy which are mostly institutional factors (e.g., prescribe curricula and examinations) and others are learner-related or teacher-related factors (e.g., lack of motivation, lack of instructions). 
Table 1

Selected Research on Learner Autonomy From Various Educational Contexts

\begin{tabular}{|c|c|c|c|c|c|c|}
\hline $\begin{array}{l}\text { Key } \\
\text { findings }\end{array}$ & $\begin{array}{l}\text { The study suggests } \\
\text { that strategy-based } \\
\text { instruction (SBI) in } \\
\text { the form of training } \\
\text { learners in } \\
\text { task-specific } \\
\text { metacognitive } \\
\text { self-regulation } \\
\text { improved learners' } \\
\text { autonomy in both } \\
\text { learning and their } \\
\text { writing ability. }\end{array}$ & $\begin{array}{l}\text { Participants } \\
\text { believed that } \\
\text { Learner Autonomy } \\
\text { should be } \\
\text { implemented, } \\
\text { however, certain } \\
\text { constraints were } \\
\text { revealed as: } \\
\text { existing } \\
\text { curriculum, lack of } \\
\text { experience and } \\
\text { guidance, national } \\
\text { examinations, and } \\
\text { lack of } \\
\text { proficiency. }\end{array}$ & $\begin{array}{l}\text { Learner } \\
\text { Autonomy is } \\
\text { partially } \\
\text { successful } \\
\text { due to certain } \\
\text { cultural } \\
\text { constraints in } \\
\text { Bulgarian } \\
\text { educational } \\
\text { context. }\end{array}$ & $\begin{array}{l}\text { Learner Autonomy } \\
\text { viewed as taking } \\
\text { responsibility and } \\
\text { control and making } \\
\text { decisions; teachers' } \\
\text { ideas about how to } \\
\text { promote LA not as } \\
\text { developed as their } \\
\text { theoretical } \\
\text { understandings of } \\
\text { the concept; lack of } \\
\text { student motivation a } \\
\text { barrier. }\end{array}$ & $\begin{array}{l}\text { Positive } \\
\text { attitudes to } \\
\text { Learner } \\
\text { Autonomy } \\
\text { found; } \\
\text { curricular } \\
\text { obstacles such } \\
\text { as fixed course } \\
\text { goals identified. }\end{array}$ & $\begin{array}{l}\text { Participants believe } \\
\text { in the importance of } \\
\text { learner autonomy, but } \\
\text { they rely on a teacher } \\
\text { in many occasions. } \\
\text { Note-taking was the } \\
\text { most used strategy. } \\
\text { Due to the traditional } \\
\text { methodology } \\
\text { followed in teaching, } \\
\text { students have } \\
\text { difficulty in changing } \\
\text { their style of learning } \\
\text { but they need } \\
\text { classroom strategy } \\
\text { training and become } \\
\text { autonomous learners. }\end{array}$ \\
\hline Methods & \begin{tabular}{|l|} 
SBI training \\
package, \\
pre-and-post \\
writing tests, and \\
delayed writing test
\end{tabular} & $\begin{array}{l}\text { Questionnaire, } \\
\text { training materials }\end{array}$ & Observations & $\begin{array}{l}\text { Questionnaires, } \\
\text { interviews (10), } \\
\text { workshops, email } \\
\text { correspondence }\end{array}$ & $\begin{array}{l}\text { Questionnaires, } \\
\text { interviews, } \\
\text { teaching } \\
\text { materials, } \\
\text { workshops } \\
\end{array}$ & $\begin{array}{l}\text { Questionnaires, } \\
\text { learner dairy }\end{array}$ \\
\hline Participants & $\begin{array}{l}130 \text { students; } 4 \\
\text { teachers }\end{array}$ & $\begin{array}{l}48 \text { teachers of } \\
\text { English (studying } \\
\text { MA at the } \\
\text { University) }\end{array}$ & N/A & $\begin{array}{l}44 \text { teachers of } \\
\text { English }\end{array}$ & $\begin{array}{l}16 \text { (numbers } \\
\text { varying at } \\
\text { different stages } \\
\text { of the study) }\end{array}$ & $\begin{array}{l}80 \text { students, } 20 \\
\text { teachers (teaching } \\
\text { English, German, } \\
\text { Albanian and } \\
\text { Macedonian) } \\
\end{array}$ \\
\hline Context & One University & One University & University & One University & One University & One University \\
\hline Country & Vietnam & Indonesia & Bulgaria & China & Japan & Macedonia \\
\hline Source & $\begin{array}{l}\text { Nguyen and GU } \\
(2013)\end{array}$ & $\begin{array}{l}\text { Lengkanawati } \\
(2017)\end{array}$ & $\begin{array}{l}\text { Boyadzhieva } \\
(2016)\end{array}$ & $\begin{array}{l}\text { Y. WANG and M. } \\
\text { WANG (2016) }\end{array}$ & $\begin{array}{l}\text { Stroupe, } \\
\text { Rundle, and } \\
\text { Tomita (2016) }\end{array}$ & $\begin{array}{l}\text { B. Xhaferi and G. } \\
\text { Xhaferi, (2011) }\end{array}$ \\
\hline
\end{tabular}

In addition to that, there are other factors, observed in the studies mentioned in Table 1, which might also contribute to hindering the development of learner autonomy. For example, certain cultural constraints which view teachers as authoritative and source of knowledge impact foster learner autonomy. However, students generally show a certain willingness to develop learner autonomy and to lead their own learning process.

\section{The Empirical Study}

\section{Aims and Research Questions}

The concept of autonomy has been widely investigated by various scholars since the second half of the 20th century. This study, however, is the first to investigate learner autonomy comparatively within Polish and Yemeni learning environments. The study addresses the following questions:

Question 1: Are there any gender differences between male and female participants with respect to learner autonomy and its sub-domains?

Question 2: Are there any differences between Polish and Yemeni participants with respect to learner autonomy and its sub-domains?

Question 3: Is there any relationship among the respective sub-domains of learner autonomy? 


\section{Participants and Instrument}

A total of 141 students participated in the present study; 82 Yemeni undergraduate students and 59 Polish undergraduate students shown in Figure 1. Polish participants are enrolled in a three-year BA program at the Institute of English Studies, University of Warsaw, where some courses are obligatory and others are selective based on students' interests. However, Yemeni participants are enrolled in a four-year prefixed BA program at the Department of English Studies, IBB University (Ibrahim Badamasi Babangida University), where names of the courses are pre-set.

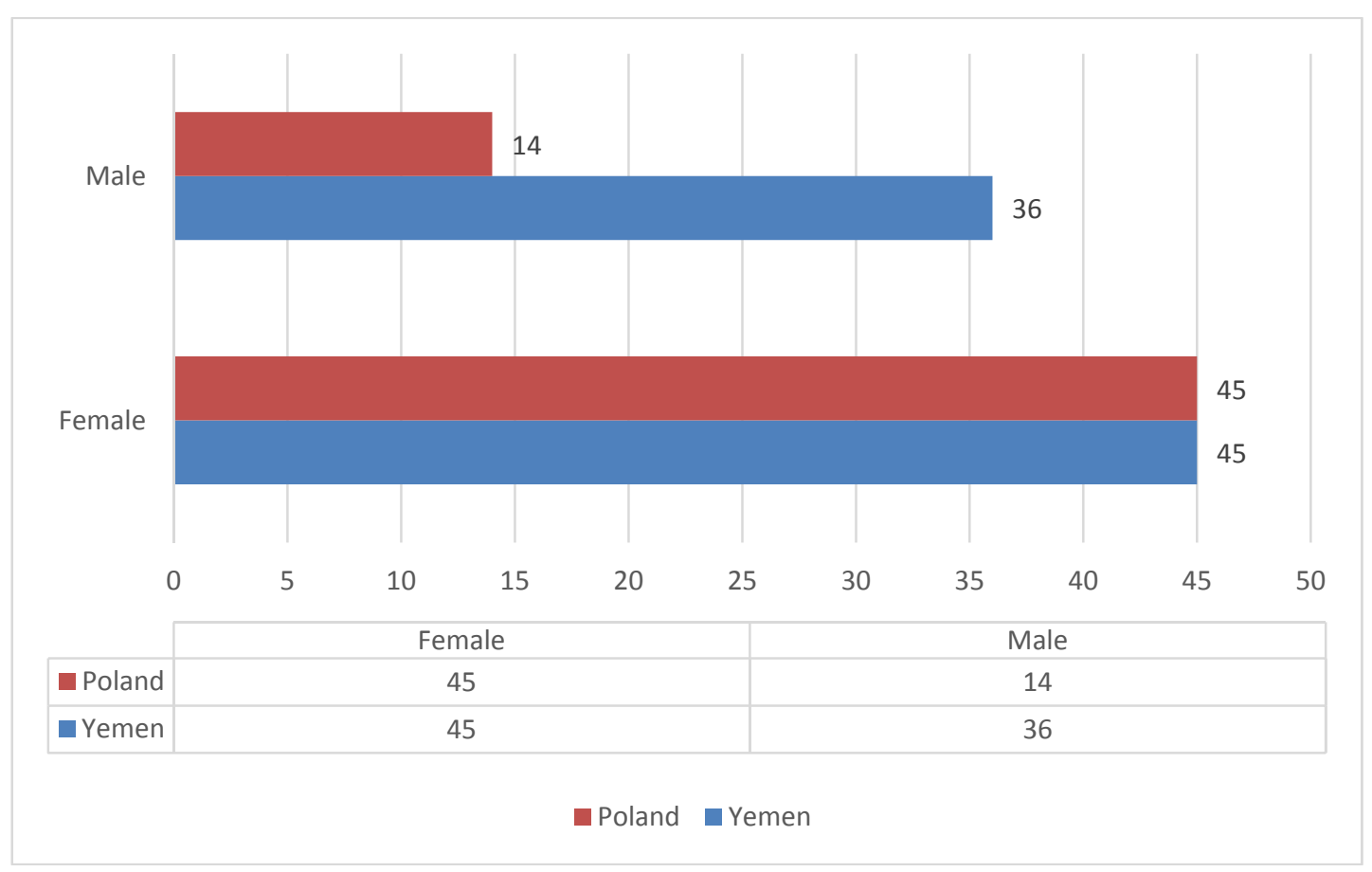

Figure 1. participants $(N=141)$.

For the purpose of the study, a questionnaire was designed to collect the data. The questionnaire, which consists of a total of 42 items, was distributed for all participants. The majority of the items in the questionnaire were adapted from Borg and Al-Busaidi (2012), Le (2013), Cotterall (2008), and Spratt, Humphreys, and Chan (2002).

\section{Data Collection, Coding and Analysis}

Based on literature review, the items of the questionnaire were categorized, after the collection of data, into seven categories (see Table 2), namely: (1) beliefs and attitudes, (2) planning, (3) management, (4) self-regulation, (5) sources and materials, (6) in-class responsibility, and (7) out-of-class responsibility. Each category consists of several items. Collected data were digitalized in order to prepare it for analytical purposes. At first, the data were coded and entered into spreadsheet. Revised in Excel, data were then transferred into SPSS for further analysis. The data of the study were analysed quantitatively because this analysis is best suited for determining relationships between groups, factors, and variables (Dörnyei, 2009, p. 9). Descriptive and statistical procedures were used to present the data and draw conclusions. 
Table 2

Sub-domains of Learner Autonomy and the Corresponding Items

\begin{tabular}{|c|c|c|}
\hline No & $\begin{array}{l}\text { Sub-domains of learner } \\
\text { autonomy }\end{array}$ & Skills/items covered in the instrument \\
\hline 1 & Beliefs and attitudes & $\begin{array}{l}\text { Thinking/believing on: ability to learn English; contributions of course materials; } \\
\text { participation in class; learning without a teacher; learning outside the class; self-study } \\
\text { engagement; enjoying tasks of own learning. }\end{array}$ \\
\hline 2 & Planning & Planning on/for: setting goals; self-studies with/without a teacher. \\
\hline 3 & Management & $\begin{array}{l}\text { Managing: free times for learning; applying strategies for my learning; noting and improving } \\
\text { weaknesses; making notes and participating in activities; selecting tasks that fits my level. }\end{array}$ \\
\hline 4 & Self-regulation & $\begin{array}{l}\text { Developing skills; answering my own questions; discovering knowledge by the self; use of } \\
\text { self-study materials; checking and reviewing homework. }\end{array}$ \\
\hline 5 & Sources and materials & $\begin{array}{l}\text { Looking for sources by myself; reading books and materials outside the class; looking for } \\
\text { more information outside the course materials; reading extra materials in advance; finding } \\
\text { resources that I need. }\end{array}$ \\
\hline 6 & In-class responsibility & $\begin{array}{l}\text { Progress inside the class; setting goals for the course; selecting activities in the class; selecting } \\
\text { topics for discussions; choosing techniques; participation in the evaluation process. }\end{array}$ \\
\hline 7 & Out-of-class responsibility & $\begin{array}{l}\text { Students are responsible for: identifying their needs; progress outside the class; choosing tasks } \\
\text { outside the class; monitoring progress; learning independently. }\end{array}$ \\
\hline
\end{tabular}

Before processing further analysis on the data, Cronbach alpha was used to test the reliability and consistency of the questionnaire. The questionnaire of learner autonomy seems to be strongly reliable. The result of Cronbach alpha test shows that the questionnaire is strongly consistent and is ready for further analysis. Table 3 shows the result of Cronbach alpha test.

Table 3

Reliability Statistics: Learner Autonomy

\begin{tabular}{lll}
\hline Name & Number of items & Cronbach alpha \\
\hline Learner autonomy & 42 & 0.837 \\
\hline
\end{tabular}

As shown in Table 3, the Cronbach alpha result for the questionnaire of learner autonomy is 0.837 which indicates strong reliability among items of the questionnaire. Accordingly, the questionnaire is deemed reliable for further data processing.

Based on the three research questions, various analytical procedures have been used to answer. Descriptive analysis has been administered to describe the research sample presented in the study. Mainly Independent-Samples $t$-Test has been used to answer the research questions addressed in the study. Correlational analysis has been carried out through Pearson to show the relationship between different items, sub-domains, and sets within autonomy.

\section{Results and Discussion}

\section{Learner Autonomy Differences Based on Gender}

The female group $(N=90)$ results on an overall response to learner autonomy $M=3.71(S D=0.43)$. By comparison, the male group $(N=50)$ results on an overall response to learner autonomy $M=3.50(S D=0.426)$. Independent Sample $t$-Test was used to test the hypothesis of gender differences in students' response to learner autonomy. The Independent Sample $t$-Test resulted in a significant difference between genders, $t(138)=2.82, p$

$=.005$. Table 4 shows the representation of the means of learner autonomy and its sub-domains. 
Table 4

Descriptive Statistics of Learner Autonomy and Its Sub-domains $(N=141)$

\begin{tabular}{lllll}
\hline Sub-domain & Gender & $\mathrm{N}$ & $\mathrm{M}$ & $\mathrm{SD}$ \\
\hline \multirow{2}{*}{ Beliefs and attitudes } & Females & 90 & 3.89 & 0.49 \\
& Males & 50 & 3.70 & 0.47 \\
\hline \multirow{2}{*}{ Planning } & Females & 90 & 3.55 & 0.66 \\
& Males & 50 & 3.29 & 0.63 \\
\hline \multirow{2}{*}{ Management } & Females & 90 & 3.57 & 0.64 \\
& Males & 50 & 3.36 & 0.77 \\
\hline \multirow{2}{*}{ Self-regulations } & Females & 90 & 3.92 & 0.56 \\
& Males & 50 & 3.50 & 0.65 \\
\hline \multirow{2}{*}{ Sources and materials } & Females & 90 & 3.35 & 0.74 \\
& Males & 50 & 3.17 & 0.76 \\
\multirow{2}{*}{ In-class responsibility } & Females & 90 & 3.58 & 0.76 \\
& Males & 50 & 3.46 & 0.70 \\
\multirow{2}{*}{ Out-of-class responsibility } & Females & 90 & 4 & 0.73 \\
& Males & 51 & 3.79 & 0.74 \\
\hline \multirow{2}{*}{ Total: learner autonomy } & Females & 90 & 3.71 & 0.43 \\
& Males & 50 & 3.5 & 0.426 \\
\hline
\end{tabular}

To test the research question with regards to the significant difference between females and males with respect to the sub-domains of learner autonomy, the Independent Sample $t$-Test was conducted. The results of the test are shown below corresponding to each sub-domain:

Beliefs and attitudes: $t(138)=2.826, p=.034$

Planning: $t(138)=2.286, p=.024$

Management: $t(138)=1.76, p=.08$

Self-regulations: $t(138)=4, p=.000$

Sources and materials: $t(138)=1.38, p=.17$

Responsibility inside the classroom: $t(138)=.872, p=.385$

Responsibility outside the classroom: $t(138)=1.65, p=.138$ 


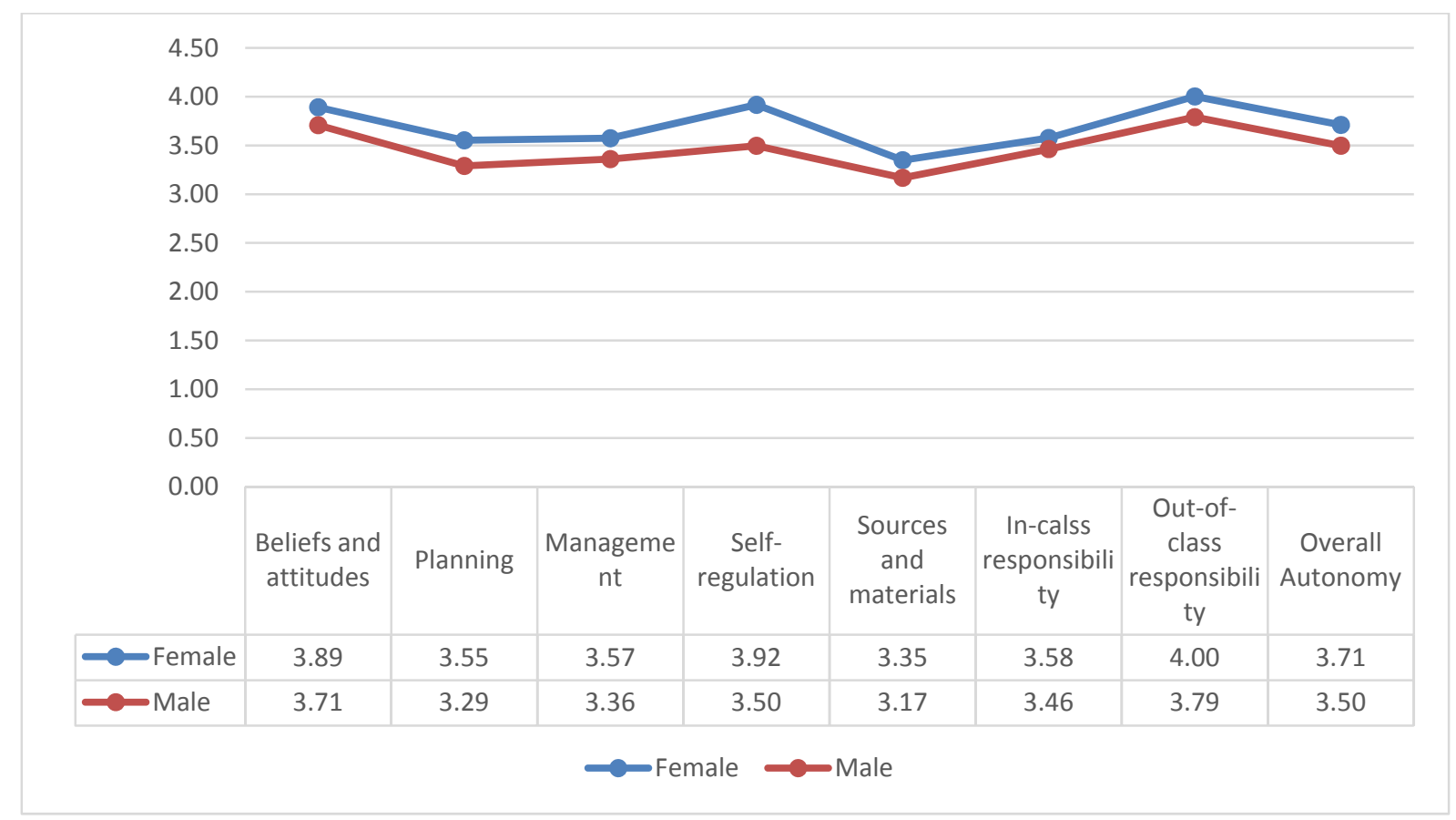

Figure 2. Males vs. females $(N=141)$.

It can be clearly inferred from the above results that there is a highly significant difference between both genders with respect to their self-regulation. Female respondents show better abilities in discovering knowledge by themselves, developing their skills, answering their own questions, and finding resources that suit their own needs. Moreover, there are significant differences between the two genders in relation to their beliefs/attitudes towards learner autonomy as well as their planning in which female respondents express higher beliefs than males and show better abilities to plan their independent learning process. Females express better ability, willingness, contribution, responsibility, and involvement in learning English compared to what males have stated. On the other hand, there are no significant differences between genders in terms of their autonomy in choosing their sources and materials as well as their responsibility inside and outside the classroom. Although statistically insignificant, a slight difference emerges between the two genders in relation to their management where females appear to be more organized and able to manage their learning process better than males.

Figure 2 represents the differences between females and males in their responses to the questionnaire of learner autonomy. Although female respondents are higher than men in all sub-domains of learner autonomy, the difference is quite stable, i.e., it goes up and down simultaneously.

\section{Learner Autonomy Differences Between Polish and Yemeni Students}

The second sub-question of learner autonomy is concerned with the differences between Polish and Yemeni participants. The statistical results of both groups vary from one sub-domain to another. At certain aspects both groups seem to have almost similar results and numerically differ in others. Table 5 presents the descriptive statistics of all sub-domains of learner autonomy and autonomy in total as well. 
Table 5

Descriptive Statistics of Learner Autonomy and Its Sub-domains $(N=141)$

\begin{tabular}{|c|c|c|c|c|}
\hline Sub-domain & Gender & $\mathrm{N}$ & $\mathrm{M}$ & SD \\
\hline \multirow{2}{*}{ Beliefs and attitudes } & Poland & 59 & 3.96 & 0.44 \\
\hline & Yemen & 81 & 3.73 & 0.51 \\
\hline \multirow{2}{*}{ Planning } & Poland & 59 & 3.45 & 0.63 \\
\hline & Yemen & 81 & 3.47 & 0.69 \\
\hline \multirow{2}{*}{ Management } & Poland & 59 & 3.49 & 0.64 \\
\hline & Yemen & 81 & 3.50 & 0.73 \\
\hline \multirow{2}{*}{ Self-regulations } & Poland & 59 & 4.02 & 0.49 \\
\hline & Yemen & 81 & 3.58 & 0.65 \\
\hline \multirow{2}{*}{ Sources and materials } & Poland & 59 & 3.40 & 0.65 \\
\hline & Yemen & 81 & 3.20 & 0.80 \\
\hline \multirow{2}{*}{ In-class responsibility } & Poland & 59 & 3.38 & 0.62 \\
\hline & Yemen & 81 & 3.65 & 080 \\
\hline \multirow{2}{*}{ Out-of-class responsibility } & Poland & 59 & 4.34 & 0.44 \\
\hline & Yemen & 81 & 3.63 & 0.76 \\
\hline \multirow{2}{*}{ Total: learner autonomy } & Poland & 59 & 3.71 & 0.40 \\
\hline & Yemen & 81 & 3.58 & 0.46 \\
\hline
\end{tabular}

To test the question if there is a significant difference between the two examined groups, the Independent Sample $t$-Test was used. The test shows that there is not a significant difference between the Polish group and the Yemeni group, $t(138)=-1.734, p<0.08$. Regardless of the fact that both groups are in two different learning environments, i.e., educational contexts, the overall results show slight differences, however, not significant. A closer analysis of the concept of learner autonomy based on its dub-domains might highlight some important aspects of the difference between Polish and Yemeni participants.

Within the concept of learner autonomy, there are five sub-domains. The differences between Polish and Yemeni participants in the five sub-domains as examined by the Independent Sample $t$-Test are visualized in Figure 3 and presented as follows:

Beliefs and attitudes: $t(138)=-2.75, p=0.007$

Planning: $t(138)=0.149, p=0.88$

Management: $t(138)=0.13, p<0.9$

Self-regulations: $t(137.7)=-4.62, p=0.000$

Sources and materials: $t(136.3)=-1.62, p<0.106$

Responsibility in the class: $t(137.6)=-2.19, p=0.03$

Responsibility outside the class: $t(131.7)=-6.69, p=.000$ 


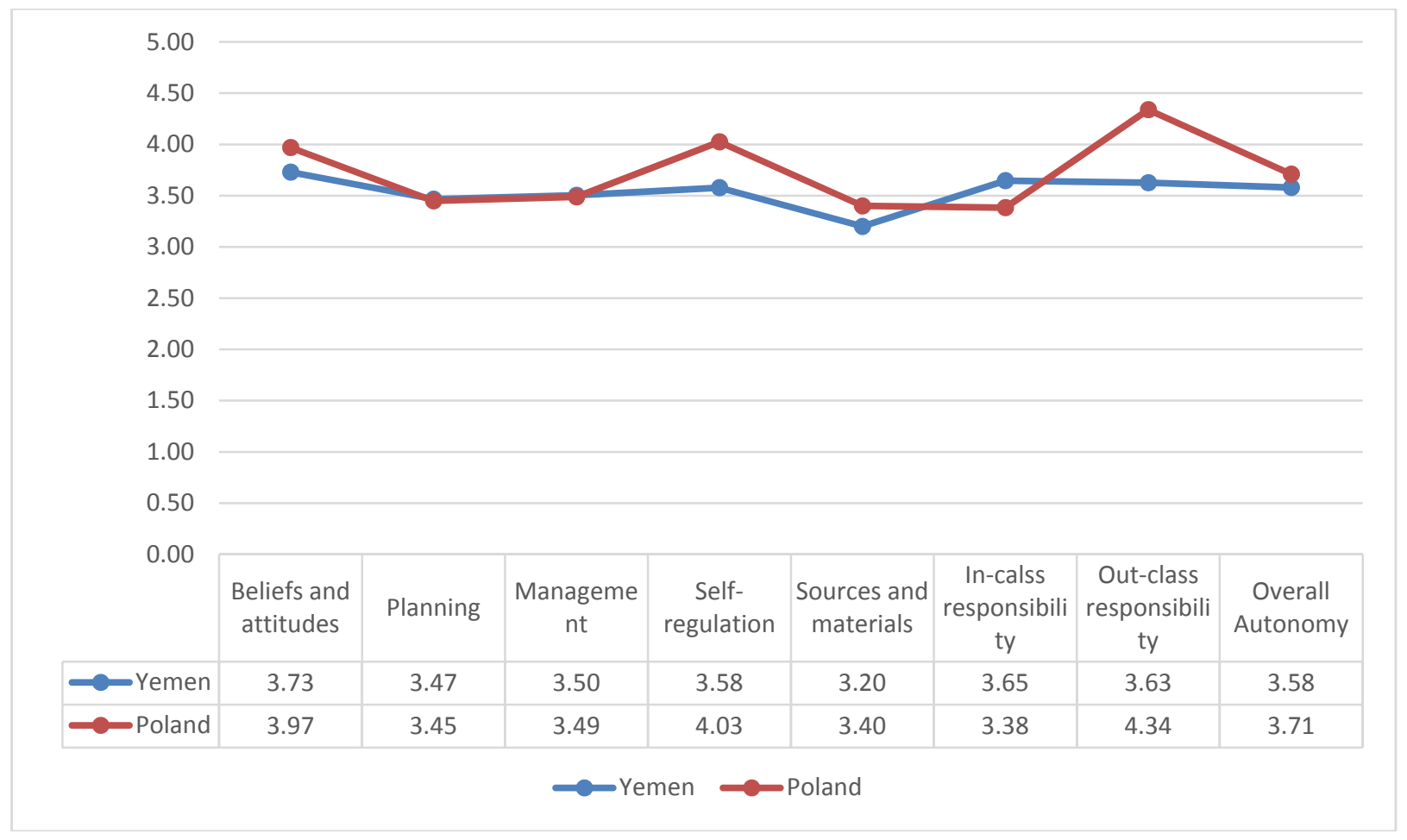

Figure 3. Poland vs. Yemen $(N=141)$.

A highly significant difference between Polish and Yemeni participants occurs in respect to their self-regulation in addition to a significant difference with regards to their beliefs and attitudes. Polish participants are more autonomous taking charge of their own learning process, developing their skills, answering their own questions, discovering knowledge, and are less dependent on teachers than Yemeni participants. In other words, Polish participants show more freedom in the learning process than the Yemeni participants. On the other hand, both groups seem to have similar practices with regards to their planning and managing their own learning. It is also worth mentioning that Yemeni participants appear to be more autonomous with regards to their in-class responsibility including their progress, setting goals, selecting tasks and topics for discussions, as well as the selections of learning materials. On the other hand, Polish participants show significantly greater autonomy with regards to their out-of-class responsibility including identifying goals, monitoring progress, and independent learning.

\section{Relationship Between Sub-domains of Learner Autonomy}

The Pearson-product moment correlation test has been used to investigate the relationship between the five sub-domains of learner autonomy. Various positive correlations appear between the different sub-domains of learner autonomy as represented in Table 6. 
Table 6

Pearson Correlation Between Sub-domains of Learner Autonomy $(N=141)$

\begin{tabular}{llll}
\hline & Autonomy sub-domains & $\mathrm{N}$ & Pearson correlation \\
\hline 1 & Beliefs/attitudes $<>$ planning & 140 & $r=0.35, p<0.001$ \\
2 & Beliefs/attitudes $<>$ management & 140 & $r=0.50, p<0.001$ \\
3 & Beliefs/attitudes $<>$ self-regulations & 140 & $r=0.61, p<0.001$ \\
4 & Beliefs/attitudes $<>$ sources and materials & 140 & $r=0.37, p<0.001$ \\
5 & Beliefs/attitudes $<>$ responsibility inside the class & 140 & $r=0.30, p<0.001$ \\
6 & Beliefs/attitudes $<>$ responsibility outside the class & 140 & $r=0.40, p<0.001$ \\
7 & Planning $<>$ management & 140 & $r=0.48, p<0.001$ \\
8 & Planning $<>$ self-regulation & 140 & $r=0.32, p<0.001$ \\
9 & Planning $<>$ sources and materials & 140 & $r=0.35, p<0.001$ \\
10 & Planning $<>$ responsibility in the class & 140 & $r=0.11, p=0.167$ \\
11 & Planning $<>$ responsibility outside the class & 140 & $r=0.15, p=0.08$ \\
12 & Management $<>$ self-regulation & 140 & $r=0.43, p<0.001$ \\
13 & Management $<>$ sources and materials & 140 & $r=0.53, p<0.001$ \\
14 & Management $<>$ responsibility in the class & 140 & $r=0.33, p<0.001$ \\
15 & Management $<>$ responsibility outside the class & 140 & $r=0.14, p=0.107$ \\
16 & Self-regulation $<>$ sources and materials & 140 & $r=0.45, p<0.001$ \\
17 & Self-regulation $<>$ responsibility outside the class & 140 & $r=0.15, p=0.077$ \\
18 & Self-regulation $<>$ responsibility outside the class & 140 & $r=0.43, p<0.001$ \\
19 & Sources and materials $<>$ responsibility in the class & 140 & $r=0.15, p=0.07$ \\
20 & Sources and materials $<>$ responsibility outside the class & 140 & $r=0.24, p<0.01$ \\
21 & Responsibility in the class $<>$ responsibility outside the class & 140 & $r=0.32, p<0.001$.
\end{tabular}

It is easily interpreted from the table above that majority of the correlations (except Number 10, 11, 15, 17, and 19) are very significant where $p<0.001$ or significant at the point of $p<0.05, p<0.01$. Correlations where $r \geq 0.5$ and above which can be classified as relatively strong correlations are represented in correlations Number 2, 3, and 13 in the table above. Above $50 \%$ of the correlations are relatively moderate positive correlation where $r<0.5$ and $r \geq 0.3$ between the corresponding sub-domains of learner autonomy. This indicates that, for instance, students who have higher beliefs/attitudes in their autonomy show greater autonomy in all other sub-domains of learner autonomy. At the same time, students who are able to plan and manage their learning processes express greater autonomy in selecting their materials, managing their time and tend to be more autonomous inside the classroom.

\section{Conclusion}

The present study is a comparative study between Polish and Yemeni EFL (English as a Foreign Language) learners with regards to their perceptions towards autonomy. Participants are 140 students at the third year of their English undergraduate programme, enrolled in two different universities and each university is backed by the local educational system (Polish and Yemeni educational system) which represents two different educational contexts. A questionnaire was distributed to the participants and data were gathered, coded, and digitalized. Answers to the questions of the study were approached via SPSS.

Three main questions were investigated in the empirical study. The first question addresses the differences between male and female respondents with respect to their learner autonomy and its sub-domains. Using the Independent Sample $t$-Test to answer the question, the results show that female respondents seem to be more 
autonomous than male respondents with a significant difference in their beliefs and attitudes, planning, and self-regulation in the sub-domains of learner autonomy. Female respondents show better abilities in discovering knowledge by themselves, developing their skills, answering their own questions, and finding resources that suit their own needs. Moreover, females express better ability, willingness, contribution, responsibility, and involvement in learning English compared to males. It is worth investigating reasons behind the advancements of females on their planning and self-regulations.

The second question addresses the differences between Polish and Yemeni respondents with respect to their learner autonomy and its sub-domains. Similarly, Independent Sample $t$-Test was used to answer the question and the results show that there is no significant difference with the overall autonomy of students. However, there appears to be a significant difference where Polish respondents show higher results than Yemeni respondents with regards to their beliefs and attitudes as well as self-regulations. On the other hand, there is a controversial view when it comes to responsibility of students inside and outside the classroom. Yemeni respondents appear to be more autonomous than Polish learners inside the classroom environment; however, Polish respondents appear to be more autonomous with respect to their responsibility outside the classroom environment. The advancement of Polish respondents over Yemeni respondents might be due to the different learning environments, educational systems, and cultural backgrounds between the two groups. However, it is worth having a closer research to see the reasons behind the advancements of Yemeni respondents over the Polish respondents with respect to their autonomy inside the classroom.

The third question addresses the relationship between the sub-domains of learner autonomy where Pearson correlation test was used to answer the question. Majority of the correlations ranges from significant to very significant correlations between the sub-domains of learner autonomy along with few insignificant correlations. Additionally, many of these correlations were classified as ranging from relatively moderate to relatively strong correlations. All in all, students who have higher beliefs and attitudes towards learner autonomy are able to show better planning and goal-oriented students seem to be more autonomous than other students. Regardless of the fact that certain learning environments might hinder the progress of learner autonomy, learner autonomy is perceived as an important that helps learners achieve their learning goals.

\section{References}

Benson, P. (1997). The philosophy and politics of learner autonomy. In P. Benson and P. Voller (Eds.), Autonomy and independence in language learning (pp. 1-12). London: Longman.

Benson, P. (2007). Autonomy in language teaching and learning. Language Teaching, 40(1), 21-40.

Benson, P. (2008). Teachers' and learners' perspectives on autonomy. Learner and Teacher Autonomy: Concepts, Realities, and Response, 1, 15-32.

Benson, P. (2011). Teaching and researching autonomy in language learning (2nd ed.). London: Pearson Education.

Benson, P. (Ed.). (2004). Learners' stories: Differences and diversity in language learning. Cambridge: Cambridge University Press.

Borg, S., \& Al-Busaidi, S. (2012). Learner autonomy: English language teachers' beliefs and practices (ELT research paper 12-07). London, $\quad$ England: British $\quad$ Council. Retrieved from https://www.teachingenglish.org.uk/sites/teacheng/files/b459\%20ELTRP\%20Report\%20Busaidi_final.pdf

Boyadzhieva, E. (2016). Learner-centered teaching and learner autonomy. Procedia-Social and Behavioral Sciences, 232, 35-40.

Ceylan, N. O. (2015). Fostering learner autonomy. Procedia-Social and Behavioral Sciences, 199, 85-93.

Clemente M. de los A. (2003). Learning cultures and counselling: Teacher/learner interaction within a self-directed scheme. In D. Palfreyman and R. C. Smith (Eds.), Learner autonomy across cultures. London: Palgrave Macmillan.

Cohn, S., \& Fraser, B. (2013). Student response systems: Impact on the learning environment, student attitudes and achievement. In Learning environments: Technologies, challenges and impact assessment (pp. 185-216). New York: Nova Science Publishers. 
Common European Framework of Reference for Languages: Learning, Teaching, Assessment. (2001). Strasbourg: Couneil of Europe; Cambridge: CUP.

Cotterall, S. (2008). Autonomy and good language learners. In C. Griffiths (Ed.), Lessons from good language learners (pp. 110-119). Cambridge: Cambridge University Press.

Dickinson, L. (1992). Learner autonomy: Learner training for language learning. Dublin: Authentik.

Dörnyei, Z., \& Taguchi, T. (2009). Questionnaires in second language research: Construction, administration, and processing. Routledge.

Duqin, W. (2002). Fostering learner autonomy in college English study. Foreign Language World, 5, 17-28.

Ellis, N. C. (2008). Implicit and explicit knowledge about language. In J. Cenoz and H. Hornberger (Eds.), Encyclopaedia of language and education: Knowledge about language (Vol. 6, pp. 119-132). New York: Springer.

Gass, S. M. (2004). Language teaching: Environment, presentation \& complexity (Plenary address). In W. HU and Q. WEN (Eds.), Papers from the fourth international conference on ELT in China: New directions in ELT in China. Beijing: Foreign Language Teaching and Research Press.

Holec, H. (1981). Autonomy and foreign language learning. Oxford: Pergamon. (First published 1979, Strasbourg: Council of Europe).

Holec, H. (2009). Autonomy in language learning: A single pedagogical paradigm or two? In F. Kjisik, P. Voller, N. Aoki \& Y. Nakata (Eds.), Mapping the terrain of learner autonomy: Learning environments, learning communities and identities (pp. 21-47). Tampere, Finland: Tampere University Press.

Huttunen, I. (2002). Facilitating language teachers to develop meaning-oriented learning environments. In V. Kohonen and P. Kaikkonen (Eds.), Quo vadis foreign language education (Reports A27, pp. 199-216). Tampere, Finland: University of Tampere.

Ismail, N., Singh, D. S. R., \& Abu, R. (2013). Fostering learner autonomy and academic writing interest via the use of structured e-forum activities among ESL students. Edulearn13 Proceedings, 4622-4626.

Kenny, B. (1993). For more autonomy. System, 21(4), 431-442.

Klimas, A. (2017) A goal-setting logbook as an instrument fostering learner autonomy. In M. Pawlak, A. Mystkowska-Wiertelak, and J. Bielak (Eds.), Autonomy in second language learning: Managing the resources. Cham: Springer.

Kohonen, V. (1992). Experiential language learning: Second language learning as cooperative learner education. In D. Nunan (Ed.), Collaborative language learning and teaching (pp. 14-39). Cambridge: CUP.

Komorowska, H. (2014). Language awareness: From embarras de richesses to terminological confusion. In A. Łyda and K. Szcześniak (Eds.), Awareness in action: The role of consciousness in language acquisition (pp. 3-20). Switzerland: Springer.

La Ganza, W. (2008). Learner autonomy - teacher autonomy: Interrelating and the will to empower. In T. Lamb and H. Reinders (Eds.), AILA applied linguistics series (Vol. 1, pp. 63-79). Amsterdam: John Benjamins Publishing Company.

Larsen-Freeman, D. (2002). Understanding language. In A. A. Pulverness (Ed.), IATEFL 2002: York conference selections (pp. 23-31). Whitstable: IATEFL.

Le, Q. X. (2013). Fostering learner autonomy in language learning in tertiary education: An intervention study of university students in Hochiminh City, Vietnam (Doctoral dissertation, University of Nottingham).

Lengkanawati, N. S. (2017). Learner autonomy in the Indonesian EFL settings. Indonesian Journal of Applied Linguistics, 6(2), 222-231.

Lennon, P. (2012). Learner autonomy in the English classroom: Empirical studies and ideas for teachers. Peter Lang GmbH, Internationaler Verlag der Wissenschaften. Eschborner Landstrasse 42-50, D-60489 Frankurt am Main, Germany.

Lewin, K. (1936). Principles of topological psychology. New York: McGraw.

Little, D. (1991). Learner autonomy 1: Definitions, issues and problems. Dublin: Authentik.

Little, D. (1999). Developing learner autonomy in the foreign language classroom: A social-interactive view of learning and three fundamental pedagogical principles. Revista Canaria de Estudios Ingleses, 38, 77-88.

Little, D. (2004). Constructing a theory of learner autonomy: Some steps along the way. In K. Mäkinen, P. Kaikkonen, and V. Kohonen (Eds.), Future perspectives in foreign language education (pp. 15-25). Oulu: Oulu University Press.

Little, D. (2006). Learner autonomy: Drawing together the threads of self-assessment, goal-setting and reflection. <http://archive.ecml.at/mtp2/ELP_TT/ELP_TT_CDROM/DM_layout/00_10/06/06\%20Supplementary\%20text.pdf >.

Little, D. (2017). Three versions of learner autonomy and their implications for English-medium degree programmes. In R. Breeze and C. Sancho Guinda (Eds.), Essential competencies for English-medium university teaching. Cham: Springer.

Little, D. \& L. Dam (1998). Learner autonomy: What and why? The Language Teacher, 22 (10), 7-8, 15. 
Manninen, J., Burman, A., Koivunen, A., Kuittinen, E., Luukannel, S., Passi, S., \& Särkkä, H. (2007). Oppimista tukevat ympäristöt: Johdatus oppimisympäristöajatteluun (Environments supporting learning: Introduction to learning-environment-thinking). Helsinki: Finnish National Broad of Education.

Mononen-Aaltonen, M. (1998). A learning environment-A euphemism for instruction or a potential for dialogue. Media Education Publication, 8, 163-212.

Murray, H. A. (1938). Explorations in personality. New York: Oxford University Press.

National Core Curriculum for the Comprehensive School. (2004). Helsinki: Finnish National Board of Education, In Finnish.

Nguyen, L. T. C., \& GU, Y., (2013). Strategy-based instruction: A learner-focused approach to developing learner autonomy. Language Teaching Research, 17(1), 9-30.

Norton, B. (2000). Identity and language learning: gender, ethnicity and educational change. Harlow: Longman: Pearson Education, 2000.

Nyman, T., \& Kaikkonen, P. (2013). What kind of learning environment do newly qualified teachers create? Scandinavian Journal of Educational Research, 57(2), 167-181.

Pawlak, M. (2017). The role of autonomy in learning and teaching foreign language grammar. In M. Pawlak, A. Mystkowska-Wiertelak, and J. Bielak (Eds.), Autonomy in second language learning: Managing the resources. Cham: Springer.

Pemberton, R., LI, E. S. L., Or, W. W. F., \& Pierson, H. D. (Eds.). (1996). Taking control: Autonomy in language learning. Hong Kong: Hong Kong University Press.

Rogers, C. R. (1961). On becoming a person: A therapist's view of psychotherapy. London: Constable.

Savage, W., \& Storer, G. (1992). An emergent language program framework: Actively involving learners in needs analysis. System, 20, 187-199.

Smith, R. C. (2003) Pedagogy for autonomy as (becoming-) appropriate methodology. In D. Palfreyman and R. C. Smith (Eds.), Learner autonomy across cultures. London: Palgrave Macmillan.

Smith, R., Kuchah, K., Lamb, M. (2018). Learner autonomy in developing countries. In A. Chik, N. Aoki, and R. Smith (Eds.), Autonomy in language learning and teaching. London: Palgrave Pivot.

Spratt, M., Humphreys, G., \& Chan, V. (2002). Autonomy and motivation: Which comes first? Language Teaching Research, 6(3), 245-266.

Stroupe, R., Rundle, C., \& Tomita, K. (2016). Developing autonomous learners in Japan: Working with teachers through professional development. In R. Barnard and J. LI (Eds.), Language learner autonomy: Teachers' beliefs and practices in Asian contexts (pp. 43-61). Phnom Penh: IDP Education.

Thanasoulas, D. (2000). What is learner autonomy and how can it be fostered. The Internet TESL Journal, 6(11), 37-48.

Veermans, M., \& Tapola, A. (2006). Motivaatio, emootiot ja oppimisen itsesäätely teknologiaympäristössä (Motivation, emotions and the self-regulation of learning in a technological environment). In S. Teoksessa, P. H. Järvelä, and E. Lehtinen (Ed.), Oppimisen teoria ja teknologian opetuskäyttö (pp. 65-84) (Theory of learning and use of technology in teaching). Helsinki: WSOY.

WANG, Y., \& WANG, M. (2016). Developing learner autonomy: Chinese university EFL teachers' perceptions and practices. In R. Barnard and J. LI (Eds.), Language learner autonomy: Teachers' beliefs and practices in Asian contexts (pp. 23-42). Phnom Penh: IDP Education.

Weinstein, C. E., Acee, T. W., Jung, J., \& Dearman, J. K. (2011). Strategic and self-regulated learning for the 21st century: The merging of skill, will and self-regulation. In Independent language learning: Building on experience, seeking new perspectives (pp. 41-54). Hong Kong: Hong Kong University Press, HKU.

Wenden, A. (1987). Conceptual background and utility. In A. Wenden and J. Rubin (Eds.), Learner strategies in language learning (pp. 159-168). London: Prentice Hall.

Wentzel, K. R. (1999). Social-motivational processes and interpersonal relationships: Implications for understanding motivation at school. Journal of Educational Psychology, 91, 76-97.

White, C. (2008). Language learning strategies in independent language learning: An overview. In T. W. Lewis and M. S. Hurd (Eds.), Language learning strategies in independent settings (pp. 3-24). Clevedon, England: Multilingual Matters.

Xhaferi, B., \& Xhaferi, G. (2011). Developing learner autonomy in higher education in Macedonia. Procedia-Social and Behavioral Sciences, 11, 150-154.

Young, R. (1986). Personal autonomy: Beyond negative and positive liberty. London: Croom Helm. 